\title{
Transnational Sex Politics, Conservative Christianity, and Antigay Activism in Uganda
}

\author{
MARCIA OLIVER \\ Wilfrid Laurier University, Canada ${ }^{1}$
}

\begin{abstract}
In October 2009, a private member introduced the Anti-Homosexuality Bill to Uganda's Parliament for consideration. This article analyzes the Bill within a broader context of transnational antigay activism, specifically the diverse ways that antigay activism in Uganda is shaped by global dynamics (such as the U.S. Christian Right's pro-family agenda) and local forms of knowledge and concerns over culture, national identity, and political and socio-economic issues/interests. This article lends insight into how transnational antigay activism connects to and reinforces colonialinspired scripts about "African" sexuality and the deepening power inequalities between the global North and South under global neoliberalism, and raises some important questions about how the racial and gender politics of the U.S. Christian Right's pro-family agenda travel and manifest within the Ugandan context.
\end{abstract}

\section{Introduction}

Now the church must wake up to the reality that the so-called "culture war" is, more than anything else, a contest between the opposing and contradictory philosophies of activist homosexuals and Christians (Lively, 2009a, p. v)

We have this-I don't know what to call it. It's some kind of invasion, a big invasion about what they think homosexuality is-a Pentecostal, evangelical invasion (personal interview March 2011).

Uganda made international headlines in October 2009 when a Member of Parliament, David Bahati, proposed the Anti-Homosexuality Bill, which would broaden the offence of homosexuality and impose harsh penalties for those who engage in, and are deemed to "promote," same-sex relations. Despite the Bill's widespread support from some of Uganda's conservative evangelical public, the proposed legislation has been highly controversial, 
rife with questions of culture and tradition, citizenship, and outside influence and power. The enacting of the Bill is not the first time that homosexuality and antigay sentiments have entered public discourse and debate in Uganda; there has been a dramatic increase in talk about homosexuality since the late 1990s (Hassett, 2007; Tamale, 2007). Nor is the Bill simply the product of Uganda's political and religious elite. Contemporary struggles and discourses around homosexuality find roots in the nation's pre-colonial and colonial history, post-colonial struggles for national identity and sovereignty, and the transnational linkages formed with conservative evangelicals in the global North.

The aim of this article is to set Uganda's Anti-Homosexuality Bill within this broader context and begin to explore the complexity of power relationships, strategies and tactics of action, and frames of meaning that are used by "principled and strategic actors" (Keck \& Sikkink, 1998, p. 2) in the struggles over homosexuality and LGBTI rights in Uganda. Examining the diverse accounts and constructions of homosexuality that circulate through conservative antigay campaigns reveals the diverse ways that sexual politics are infused with transnational and local forms of knowledge and power struggles over "which sexual desires, acts, identities, and relationships should be socially supported and which should be socially punished and repressed" (Seidman, Fischer, \& Meeks, 2006, p. 430). This examination also raises some important questions about how transnational antigay activism connects to and reinforces colonial-inspired scripts about "African" sexuality and deepening power inequalities both within Uganda and between the global North and South under global neoliberalism. Yet, as post-colonial scholars and activists have pointed out, it is not only antigay values and discourses that embody neo-colonial assumptions and practices. Rather, often lurking beneath the apparent defense of gay and lesbian rights by Northern activists and donors (including the latter's threat to cut aid to governments that persecute homosexuals) are racialized and paternalistic assumptions that view the "West" as the guardian of civilization and modernity and "Africa" as a homogenous site of homophobia and unbridled violence. Accompanying this racialized discourse is the re-positioning of "African" sexual minorities as "victims" in need of Western protection and liberation (Haritaworn, 2012; Kalende, 2011; Puar, 2007).

This paper is inspired by the rise of conservative Christianity in global politics, which is often overlooked in studies on transnational activism. With a few notable exceptions (e.g., Buss, 2004; Buss \& Herman, 2003; Haynes, 2001; Hassett, 2007; Hearn, 2002), these studies have focused mainly on forms of activism that are considered "progressive" or "left-wing," such as those concerned with issues of social justice, human rights, humanitarian aid, and neoliberal development. Rather than focusing on the realm of progressive pro-gay activism that has emerged trans/nationally to support sexual minorities and LGBTI rights in Uganda, this paper focuses on the representations of homosexuality that are produced by and circulate through conservative evangelical networks between the global North and South 
(Hassett, 2007; Lewis, 2004). As Kaoma's (2009) research reveals, it is many of the same U.S. Christian Right organizations (hereafter CR) that are active in domestic antigay politics that are playing a role in African antigay politics. Moreover, Herman's (1997) observation that the CR's antigay activism is primarily a White movement in the U.S. also holds at the international level; it is primarily White, Christian, pro-family organizations (directed by men) that are leading the CR's "pro-family" agenda at the international level and are a visible presence in Uganda's recent wave of antigay activism. This raises some important questions about how the racial politics of the CR's so-called family values travel and manifest within the Ugandan context, values which, according to McWhorter (2009), have been racialized and gendered all along. Yet, this is not simply a matter of Northern White conservatives exporting their antigay agenda to a "passive" global South (Anderson, 2011; Hassett, 2007). Some of the most vocal religious and political antigay activists in Uganda have connections with $\mathrm{CR}$ actors and organizations (including President Museveni, MP David Bahati, and Reverend Martin Ssempa). Moreover, rather than simply reproducing $\mathrm{CR}$ discourses, conservative Ugandan leaders formulate their antigay positions by drawing on culturally specific discourses and concerns that not only resonate with the wider public (Anderson, 2011), but also may help serve their own interests and political ends.

My analysis is loosely informed by materialist feminist accounts of power that attend to both the politics of representation and the material and structural forces that shape social relationships and practices in certain (and unequal) ways, including colonialism, imperialism, patriarchy, religious fundamentalism, and global capitalism (see Jackson, 2001). These accounts remind us that although discourse and cultural representations are integral to the constitution of social life and the formation of particular subjectivities (see Lewis, 2011), they cannot fully account for the structural inequalities characterizing local and global contexts that benefit some people and entire nations while excluding, regulating, exploiting and, at times, inflicting violence on marginalized others. This point alerts us to the egregious effects of anti-gay activism on the lives of sexual minorities throughout the world, which in Uganda include being denied access to social services, having their personal details published in national tabloids (e.g., Rolling Stone and Red Pepper), and horrific forms of harassment (death threats), violence, and even death, such as the murder of Ugandan gay rights activist, David Kato, in January 2011.

My analysis also draws on a small but growing body of scholarship that has emerged since the introduction of the Anti-Homosexuality Bill (2009). Scholars have analyzed the Bill in terms of its legal content and implications (Tamale, 2009; Civil Society Coalition, 2009; Human Rights Watch, 2009), media representations of homosexuality (Vanderbeck, Andersson, Valentine, \& Ward, 2012) and pro-gay advocacy efforts (Strand, 2011), and international debates over sexual orientation (Anderson, 2011). This paper contributes to these studies by examining the diverse ways that antigay activism in Uganda is shaped by global dynamics (and in particular the U.S. Christian Right) and 
local forms of knowledge and concerns over culture, national identity, and political and socio-economic issues/interests. The following analysis is based on on-line newspaper articles, editorials and commentaries from international and national sources, audio and video coverage of public speeches and antigay seminars, position papers of evangelical and human rights organizations, and interviews with human rights activists that I conducted in Kampala in May 2008 and March 2011. This article is divided into two sections. The first section attempts to contextualize the emergence of the anti-homosexuality bill by highlighting its key provisions, the diverse range of national and international responses it provoked, and the rise of the U.S. Christian Right in global struggles over sexuality and recognition of gay and lesbian rights. I offer some insights into why the $\mathrm{CR}$ has turned its attention to the international realm and, more specifically, to Africa to spread its "pro-family" agenda, highlighting its relationship with other elements of global Christianity that are more firmly entrenched in Uganda's colonial history. The second section maps the forms of trans/national knowledge shaping antigay campaigns in Uganda, with a particular emphasis on the local manifestations of Christian Right discourse, and attempts to think through some of the ways that antigay campaigns serve as a vessel for sustaining and challenging broader global insecurities and inequalities.

\section{Situating Uganda's Anti-Homosexuality Bill}

On October 14, 2009, Ugandan Member of Parliament David Bahati introduced the Anti-Homosexuality Bill to Uganda's Parliament, known in some circles as the "Kill the Gays Bill," the "Bahati Bill," and the "Anti Human Rights Bill." Although homosexuality is already an offence under the current Penal Code Act (a legacy of the British colonial era), this Bill seeks to "fill the gaps" in the provisions of existing laws by serving as a "comprehensive and enhanced legislation to protect the cherished culture of the people of Uganda" and to "strengthen the nation's capacity to deal with emerging internal and external threats to the traditional heterosexual family" (Bill No.18, 2009). Of particular concern, the Bill identifies "the attempts of sexual rights activists seeking to impose their values of sexual promiscuity on the people of Uganda" (ibid). The proposed law further criminalizes homosexuality to include "attempted" homosexuality, the "promotion" of homosexuality and the failure to disclose knowledge of any offence under the Act to relevant authorities within twenty-four hours. It imposes mandatory testing for HIV and the death penalty for certain acts classified as "aggravated homosexuality." Finally, the Bill allows Uganda the opportunity to nullify any international treaty, protocol, or declaration that contradicts the spirit of the Bill and applies to Ugandan citizens who commit an offence under this legislation while outside the country (Bill No. 18, 2009). At the time of this writing, the Bill is under review by Uganda's Legal and Parliamentary Affairs Committee, which is required by parliamentary procedure to examine 
proposed legislation, make recommendations, and return the Bill to the House for debate and vote. Based on a previous report to Parliament, if the Committee endorses the Bill, it is likely that it will recommend removing the death penalty for certain homosexual acts (Ni Chonghalle, 2012) and the provisions that criminalize "attempted" homosexuality, "conspiracy to commit homosexuality," failure to disclose homosexuality, and the clauses granting extra-territorial jurisdiction (Human Rights Watch, 2011). Human rights activists have warned that even if President Museveni refuses to assent to the Bill, Uganda's Constitution stipulates that a bill can become law with the support of at least two-thirds of Parliamentary members.

International and national responses to the Bill have been divided, with support mainly voiced by other African nations considering similar legislation and some of Uganda's (mostly Pentecostal) religious leaders and political elites, many of whom have connections with CR actors and organizations. For instance, Jeff Sharlet's (2008) research connects David Bahati, James Buturo, and President Museveni to the Fellowship (otherwise known as the Family), a broad network of evangelical organizations, with extensive links to the White House and the host of the National Prayer Breakfast in Washington; Pastor Martin Ssempa (an outspoken advocate of the Bill) has close ties with California mega-church Pastor Rick Warren; and Steven Langa of Uganda's Family Life Network has hosted numerous antigay rallies with U.S. antigay speakers (such as Lou Engle from The Call). In addition, there are also many religious and political leaders who agree with the overarching spirit of the Bill, but reject the severity of some of its provisions (namely the death penalty). They include a number of CR organizations and members who have distanced themselves from the Bill (including US pastor Rick Warren and Holocaust-revisionist Scott Lively) (see Kwon, 2009), as well as Uganda's Catholic and Anglican Church leaders who have publicly condemned the Bill as "un-Christian," while retaining the view that homosexuality is immoral and a violation of God's will and supporting tougher legislation on homosexuality. $^{2}$

The Anti-Homosexuality Bill has also been widely and fervently opposed by international and national pro-gay activists and supporters, including sexual minorities, human rights advocates, feminists, public health and HIV/AIDS organizations, academics, and international donors (with some threatening to cut aid if the Bill is passed, like Britain and the U.S.). There is also a small number of religious leaders in Uganda who have contested the Bill on human rights grounds, arguing that "homosexuals should enjoy all the rights and benefits that heterosexuals enjoy" (Ssenyonjo cited in Hasselriis, 2010). Of particular note is retired Bishop Christopher Ssenyonjo, who has been a consistent voice for LGBTI equality in Uganda, offering ministry to sexual minorities and speaking out at human rights conferences, urging people to understand the complexities of human sexuality and, above all, to love one another as God loves all human beings. ${ }^{3}$ One of the most significant initiatives to emerge in response to the Bill is the Civil Society Coalition on Human Rights and Constitutional Law, established in October 2009 by 
a small number of LGBTI organizations [personal interview March 2011]. Today, the coalition consists of roughly fifty civil society organizations that have been at the forefront of exposing the repressive and unconstitutional effects of the Bill for all Ugandans (see Civil Society Coalition, 2009; Strand, 2011; Tamale, 2009).

Human rights activists have also reached out and forged new international allies with Western NGOs and lobbied Western state leaders to denounce the Bill; they have emphasized the human rights and public health implications of the Bill and pressured government ministries to include LGBTI concerns (e.g., Ministry of Health on HIV/AIDS); and they have engaged the public in dialogue about sexuality in relation to questions of culture and tradition, Christian values, individual choice and privacy, state responsibility, and continued neocolonial influence [personal interviews March 2011]. Finally, they have refused to treat LGBTI rights as a single or "special" issue, choosing instead to entrench LGBTI rights within a broader social justice movement that opposes all forms of oppression and is committed to building an inclusive human rights culture in Uganda and throughout the continent. A significant part of this struggle is challenging Western donors, feminists and gay and lesbian activists for supporting racist and imperialist campaigns that equate "African" countries with homophobia and sexual repression and "Western" countries with a "modern" progressive and liberated sexuality. This is particularly relevant in the post $9 / 11$ era, which has witnessed not only a reinvigorated heteronormative nationalism that celebrates heroic White men for "saving" non-White women from repressive regimes, but also the emergence of what Jasbir Puar has called "homonationalism": a "modern" Western normative homosexual identity which displays the "right" patriotic values and authorizes nationalist projects in the name of freedom (2007, pp. 39, 46; see Haritaworn, 2012).

Questions of Western power and influence have also been raised with regards to the timing of the Bill, which was introduced just months after three CR speakers led a seminar in Kampala (in March, 2009) on "Exposing the Truth about Homosexuality and the Homosexuals' Agenda." They were Caleb Lee Brundidge, an ex-gay man and member of Richard Cohen's International Healing Foundation for homosexuals, Don Schmierer of Exodus International, an umbrella group for ex-gay advocacy organization, and Scott Lively, president of California's Abiding Truth Ministries and coauthor of The Pink Swastika (which claims that Nazism was, at its core, a militaristic homosexual movement). Although much international attention has identified this seminar as a key moment in the Bill's creation, there is nothing particularly unique about this event or the antigay rhetoric espoused there. Conservative Christians have been formulating their antigay positions in the U.S. for decades (see Herman 1997) and they have been an increasing presence in global politics concerning gender and sexuality-related matters since the mid-1990s and even more so in Africa in the last decade (as I elaborate below). In 2005, the BBC's "Focus on Africa" reported: "Africa is being colonized and Christianized all over again. The colonizers this time 
are American, not Europeans, and the brand of belief they are bringing to Africa is Evangelical Christianity" (cited in Huliaras, 2008). Thus, the Scott Lively et al. seminar offers a glimpse into the shifting terrain of the CR's global activism and the local manifestations of CR's antigay discourses in the global South.

\section{The U.S Christian Right and the Global "Pro-Family" Movement}

The U.S. Christian Right is a powerful force in shaping national and global struggles over sexuality and recognition of gay and lesbian rights. Its membership is conservative, largely evangelical Protestant, and white, though it has increasingly reached out to African Americans for support on religious and social issues (but much less so on economic issues) (Wilcox, 1990). For my purposes here, I am less concerned with the CR's constituency and more with the "broad coalition of pro-family organizations and individuals who have come together to struggle for a conservative Christian vision in the political realm" (Herman, 1997, p. 9). The CRs politics are also antifeminist and anti-welfarist; it blames the welfare system for destroying the "natural" family, most notably for marginalizing men from their "provider" role and fostering a culture of dependency (and sexual promiscuity) amongst the poor. Although the CR's politics are rhetorically gender- and race-neutral, it is African Americans, Hispanics, and single women who are overrepresented amongst the U.S. (and global) poor and thus the main targets for welfare reform and "family-strengthening" programs. With deep political ties to the Republican Party and equipped with a well-funded and highly organized infrastructure, the CR has exerted significant influence in shaping national policies in terms of its minimalist state and socially conservative worldviews. More recently, it has extended its reach and influence globally, forging alliances with other conservative evangelical Christians and orthodox faiths around the world to defend the moral foundations of society against the perceived dangers of an encroaching "global liberal agenda" (Buss and Herman, 2003). While there is nothing "natural" or "traditional" about the CR's vision of the family, it has come to inform a worldwide alliance that is mobilized around defending a particular vision of the family as "inscribed in nature and defined by heterosexual marriage whose primary purpose is procreation" (Buss, 2004, p. 57).

The CR's global reach and influence can be seen in the explosion of Christian Right broadcasting in the global South, such as the Christian Broadcasting Network, a "global ministry committed to preparing the nations of the world for the coming of Jesus Christ through mass media" (CBN website). The CBN airs gospel programs (e.g., The $700 \mathrm{Club}$ ) in more than 136 countries around the world, including 38 different African countries, and distributes videos and literature through an elaborate global network of national and regional television stations, Ministry Centers, and a range of humanitarian projects and missionary activities (ibid). The CR's global 
influence can also be seen in U.S. foreign policies on family planning and HIV/AIDS prevention (especially the latter's emphasis on abstinence and fidelity programs), its increased activism at the United Nations, as well as in the enormous growth of conservative evangelical organizations working overseas since the 1990s (Hearn, 2002).

This begs the question: why has the Christian Right turned its attention to the international realm at this particular moment and, more specifically to Africa, to spread its "pro-family" and antigay agenda? Since the mid1990 s, a number of events have transpired that offer some insight into this development. First, a number of United Nations (UN)-hosted conferences on the rights of women and population policy stirred concern among CR organizations that the UN was promoting world government and liberalsecular values that threatened to destroy the "traditional natural" family. To grasp the utter dread that this provoked among CR actors, it is important to consider CR understandings of biblical prophecy and the second coming of Christ. Although end-times accounts vary, more recent evangelical writings (like the "Left Behind series") associate the Anti-Christ with the United Nations and cultural degeneration (Herman, 1997). Thus, for some conservative Christians, the emergence of terms like "sexual orientation," "sexual rights," and "gender identity" in official UN documents (e.g., the Beijing Platform for Action, 1995) signaled the rise of a satanic agenda: an explicit attack against Christian faith and, most notably, the "natural" family. Numerous Christian Right groups have been granted consultative status as NGOs at the UN (including Focus on the Family, Concerned Women for America, and the Family Research Council) and numerous scholars have documented the significant role played by the Christian Right in building alliances with other evangelicals and orthodox faiths (e.g., Jewish and Muslim groups) to prevent this language from entering final UN documents and agreements (Anderson, 2011; Buss and Herman, 2003; Chamberlain, 2006; Petchesky, 2000).

Second, recent debates and divisions within the Anglican Communion over issues of homosexuality have provided fertile ground for CR actors and renewal movements (like those of the Institute on Religion and Democracy) to join forces with conservative Episcopalians and allies in the global South to defend Biblical sexual morality. ${ }^{4}$ As Miranda Hassett (2007) notes, beginning in the mid-1990s, Episcopal conservatives began to reach out to Southern church leaders out of frustration with the loss of orthodoxy in the U.S. Episcopal Church (e.g., blessing same-sex unions and ordaining gay and lesbian bishops). A key aspect of this development is the changing demographics and power dynamics within the Anglican Communion itself, with power increasingly concentrated in countries that were former British colonies. With roughly 80 million members worldwide, over 30 million of its members reside in Africa (with the vast majority living in Nigeria, Uganda and Kenya) (Kaoma, 2009). As such, African bishops have become prominent players in Anglican Communion politics, especially in defending biblical orthodoxy on matters of human sexuality. For instance, at the 1998 
Lambeth Conference, African bishops were integral to passing a resolution that declared homosexuality to be "incompatible with Scripture" and recommended against the blessing of same-sex unions and the ordination of homosexuals as bishops (see Anderson, 2011; Hassett, 2007; Hoad, 2007). Moreover, following the U.S. Episocopal Church's decision in 2003 to ordain an openly gay man, Gene Robinson, as Bishop of the Diocese of New Hampshire, several Southern provinces have broken ties with the Episcopal Church, rejected funding from mainline denominations (The Washington Times, 2005), and offered their churches to US Episcopal dissidents. The Church of Uganda has become a popular "spiritual home" for U.S. churches that have declared independence from the Episcopal Church (Hassett, 2007) and, as Daly (2001) notes, Ugandan bishops comprise the largest contingent in the U.S. conservative Episcopal movement's growing international network.

Third, the election of former President George W. Bush (a self-identified born-again Christian) bolstered the CR's global reach. Christian conservatives attained a level of political power within the Bush administration that is unprecedented in U.S. history and many of its foreign policies reflect this Christian influence (especially concerning sexuality-related matters like abortion, HIV/AIDS, and international trafficking). ${ }^{5}$ Moreover, through a number of faith-based initiatives, President Bush further eroded the boundaries separating church and state and drastically increased the amount of federal funding and the number of contracts available to faithbased organizations. ${ }^{6}$ While this increased engagement with faith-based organizations is clearly part of a broader shift in development thinking that relies on an expanding civil society to deliver services to the poor, it is also a "vital component in the globally expanding evangelical network between the northern and southern hemispheres" (Hofer, 2003, p. 375). Moreover, the Bush administration's response to the terrorist attacks of 9/11 fused Christian morality with neoconservatism's pro-militarism in unprecedented ways. Not only was the war against global terrorism justified in religious terms, pitting the "goodness" of Christianity against the "evil empire" of Islam, but it also entailed a renewed U.S. nationalism that was tied to (W)hite, heterosexual norms and expectations (Puar, 2007). Recall that it was Christian Right folks like Jerry Falwell who blamed the "pagans, and the abortionists, and the feminists, and the gays and lesbians" for the attacks (CNN, 2001). Moreover, racist depictions of Muslim women as " "victims' of violence or of 'Islamic barbarism"” (Haritaworn, 2012, p. 73) provided yet another justification for G.W. Bush's mission to spread freedom around the world and support a Christian-based pro-family agenda.

Finally, the CR's growing interest in Africa can be seen as part of a broader change in political strategy that emerged in the U.S. in the early 1990s. Anticipating that the movement's history of racism (e.g., claiming a Biblical basis for segregation) might hamper its fight against liberal-secularism and moral corruption, Christian Right leaders sought to disrupt any potential alliance that may form between gay and Black communities. In doing so, they began calling for racial reconciliation and urging White followers to transcend 
racial and denominational barriers (see DeParle, 1996), while simultaneously manufacturing antigay campaign materials that positioned White gay and lesbians as threats to Black civil rights (Stone \& Ward, 2011). The racial underpinnings of the "natural" (Euro-American) family are mitigated by the emphasis on universal "post-racial" Christian values, which has become the foundation of the CR's global activism and is widely regarded as the future of a worldwide conservative evangelical movement. This movement calls for Christian Unity in Jesus Christ and a revival of biblical orthodoxy as the basis for moral-political order throughout the world.

It is these values that enable the CR to reach out and forge alliances with other conservative elements of global Christianity and revival movements that have a much longer history and hold on Africa, such as Anglicanism (which spread around the globe with British colonialism). In Uganda, the first Anglican missionaries arrived in Buganda in 1877, a Kingdom in what is today the southern part of the country. French Catholic missionaries arrived in 1879 and proponents of Islam in the 1840s (Hassett, 2007). Following years of religious conflict, the arrival of the British in the 1890s assured the dominance of Anglicanism in the region. ${ }^{7}$ The regulation of familial, gender, and sexual relations was central to colonial rule and its "civilizing" missions. In contrast to the "superiority" of "Western" Victorian bourgeois mores, "African" bodies and sexualities were depicted as primitive, deviant, and ruled by instinct and sexual desire (Tamale, 2011). By depicting Black people as the essence of nature, colonialists could not imagine African sexuality to be anything but heterosexual and procreative (Lewis, 2011). Through a broad range of tactics, colonial authorities targeted those aspects of Ugandan culture that were deemed "immoral" and against the "laws" of nature. For instance, colonial laws based on Judeo-Christian values were enacted to "encourage" Ugandans to reject their "immoral" ways and to adopt the Victorian White patriarchal family as the site for sexual expression and procreation. One of the lasting legacies of British colonialism is legislation criminalizing homosexuality, such as Uganda's current Penal Code that defines homosexuality as a crime "against the order of nature."

The East African Revival of the 1930s and 1940s is also central to the development of Christianity in Uganda. Known as the Balokole (the Saved ones), the movement offered individuals a deeper experience of Christianity with its emphasis on high moral standards and clean living, open confession of sin, and conversion or receiving salvation in Christ (Ward, 2012). The Balokole movement has been central to reactivating Protestant spirituality in Uganda, and it is key to understanding the Anglican Church's moral energy and influence in debates over homosexuality both nationally and within the global Anglican Communion (Hassett, 2007). Moreover, in the last few decades, Uganda has seen an influx of Pentecostal churches, whose lively and creative worship style is particularly appealing to the young and educated. This has posed significant challenges to the Church of Uganda and the Catholic Church, with many churches responding by injecting the strengths of Pentecostalism into its worship style and spirituality (Hassett, 
2007; Kasibante, 2012). Although competition and divisions exist within Christianity in Uganda, these are minimized by the broader global trend in conservative Christian movements to emphasize the power of Christian Unity in defending biblical "fundamentals." In the words of Pastor Samuel Mukiibi (of the Uganda Revival Network), "the outpouring of the Holy Spirit is now evident in almost all Christian denominations. The Lord is doing something new. He is changing people's perceptions about salvation, especially those who have been limiting it to their denominations" (Vision Reporters, 2010a).

Opposing homosexuality is one issue that unites conservative Christians globally, albeit, I would argue, in diverse ways and for diverse reasons. There is also an almost exclusive concern with male homosexuality, especially the dangers it presents to boys. As Sylvia Tamale (2007) argues, the erasure of lesbian sexuality in African societies reinforces a normative hetero-patriarchal gender hierarchy whereby women's sexuality is reduced to reproduction and "real" sex is defined in terms of penetration and male desire. When lesbianism is present in anti-gay discourses, it is often confined to psychological frameworks that provide explanations for the "causes" of women's same-sex intimacies, such as sexual abuse. The following section examines how homosexuality and the LGBTI movement are constructed through trans/national antigay campaigns in Uganda and also attempts to situate these within broader considerations of global power inequalities and insecurities.

\section{Transnational Sex Politics: Representing Homosexuality and the LGBTI Movement}

Numerous studies have documented the sexual and racial politics of antigay and gay movements in the United States, highlighting the use of Blackness by Whites to achieve specific moral and political ends (see Stone and Ward, 2011; Herman, 1997). Less has been said about how the CR's racial politics shape its international activism and, in turn, how racial arguments manifest themselves and are translated in national and local contexts in the global South. As I noted above, CR groups have stressed racial reconciliation since the 1990s in an effort to gain African American support for their moral and political agendas, while simultaneously supporting anti-immigration and anti-welfare policies. The CR's global activism can therefore be seen as an extension of this shift in political strategy, with universal, post-racial Christian "family values" serving to mitigate the racial and colonial legacies of the "natural" (White) family (McWhorter, 2009).

\section{Sin and Civilization}

Perhaps the most obvious way that conservative Christians across the globe promote post-racial pro-family values is through declarations of biblical 
"Truth" that identify homosexuality as an irrefutable sin, an immoral act condemned by God. This position is well rehearsed in CR antigay discourse by Ugandan religious and political leaders and is widely circulated through the Ugandan press (Eyalama, 2008; Kagolo, 2010; Muhofa, 2008). According to the Church of Uganda's formal position on homosexuality, "homosexual practice has no place in God's design of creation, the continuation of the human race through procreation, or His plan of redemption" (Church of Uganda, 2009). While it is clearly the case that biblical injunctions against homosexuality unite conservative Christians across the globe, it is important to situate African bishops' positions against homosexuality as part of a broader response to the perceived loss of orthodoxy within the Anglican Communion itself and their insistence on the "right to speak for, and as, the Anglican universal" (Hoad, 2007, p. 66). Moreover, as Ugandan churches face increased competition to retain or attract new members, antigay rhetoric is one way for religious leaders to build their public standing by demonstrating their commitment to biblical morality and their refusal to submit to perceived Western sexual norms. Take, for example, the antigay actions of Pentecostal preacher, Martin Ssempa, who has attracted international attention for showing gay fetish pornography and providing graphic depictions of gay sex to members who attend his antigay workshops (see BBC News, 2010). Ssempa's performance reflects what Desiree Lewis (2011) calls a "theatrical display of patriarchal authoritarianism" (p. 212), whereby political and religious leaders gain public support by engaging in performative displays of power (or spectacles) to demonstrate their commitment to the nation and practices defined as "African" (Lewis, 2011, p. 211). I would add that Ssempa's controversial performances can also be understood in more crude market terms, whereby pre-existing antigay sentiments in the country are purposefully exploited in an effort to attract new congregants while simultaneously bolstering his public standing at national and international scales.

As seen above in the Church of Uganda's formal position on homosexuality, biblical injunctions are often accompanied by fears over reproduction and the decline of human civilization. For instance, the former Ethics and Integrity minister, James Nsaba Buturo, warned the Parliament that "if the Government were to legalise marriages between men and men and women and women, we would be talking about a threat to human civilization" (quoted in Olupot \& Musoke, 2009). Newspaper commentaries echo this concern: "If all of us were to become gay, where would the next generation come from?" (Muhanga, 2009); "Scientifically, sex is a means to an end, the end being the propagation of the human race" (Eyalama, 2008); "Homosexuality [is] one way of making the world extinct" (Namutebi, 2008). Sadgrove and others (2012) have contextualized these concerns in relation to constructions of marriage and childbearing in Uganda, noting that these familial arrangements are often considered essential to the acquisition of material goods and the wellbeing of extended kinship groups. Thus, claims made in the name of an individualized gay or lesbian identity signal the rejection of one's reproductive 
responsibility, which is perceived to threaten both "the nature of the family and, at a deeper level, social relations within Uganda" (Sadgrove et al., 2012, p. 119). This is particularly significant in the context of global neoliberalism, which, in the name of free market competition, has deepened inequalities and shifted the responsibility of welfare to individuals and families.

Of course, concerns over reproduction and civilization are also deeply entrenched in colonial and Euro-American discourses, which have relied on racialized constructions of the "normal" and "natural" White heteropatriarchal family as superior to (and in need of protection from) the predatory sexual practices of racialized others and gender deviants. Within this logic, homosexuality was constituted as a threat to the White nuclear family and, more importantly, to the continuation of the White race (McWhorter, 2009). Today's manifestation of this legacy is complex, especially in the context of an emergent global movement that is mobilized to defend the "natural" family. In many ways, the explicit racism of imperial "civilized" sexual norms has largely been mitigated by a Christian universalism based on biblical orthodoxy (Hoad, 2007), which partly explains the shared obsession of the U.S. Christian Right and African religious elites with sexual deviation from hetero-patriarchal family forms. However, race is also made more explicit in the rhetorical and political antigay strategies of the U.S. Christian Right and, more recently, contemporary trans/national antigay campaigns, whereby "Blackness is invoked by [Christian] conservatives as the opposite of, and yet fundamentally vulnerable to, homosexuality" (Stone and Ward, 2011, p. $610)$.

\section{Politics of Immutability and Antigay Rights}

Positioning gay and Black communities as mutually exclusive and oppositional groups has been a key political strategy of the U.S. Christian Right since the 1990s. In the U.S. context, these campaigns were designed to disrupt any potential solidarities that may arise between gay and Black voters by depicting lesbian and gay men as White "minority imposters" who are undeserving of civil rights (Stone \& Ward, 2011). White CR actors have pursued this strategy globally by distributing knowledge and quasi-scientific "facts" to African audiences to frame homosexuality as distinct from race as a chosen, rather than innate, behavior. For instance, Scott Lively told his Kampala audience:

They say "gays are born that way and it has been "proved." That is a lie. That is what's called a lie. It is not true. There is no definitive scientific study that has ever proved that homosexuality is innate. . . Now let's bring in race, let's bring in skin colour because this is really common in the United States and around the world in which race is being used as equivalent to homosexuality to claim rights. . . . How many people can tell me what's wrong, what's morally, physically, behaviourally wrong with having a black skin? ... So you can really see that there's absolutely nothing that correlates between skin colour and 
homosexuality. (2009b)

As Lively's words illustrate, the CR's global activism involves more than biblical orthodoxy; it also relies on secularized antigay Right messages that construct homosexuality as a willful behavioural choice (unlike race) that is undeserving of rights. This logic is reiterated by the former Ethics and Integrity minister, James Buturo, who stated, "Ugandans have rejected this labeling or marketing by arguing that homosexuality is not an in-born condition like race and colours are. . . They do not accept that it is a human rights issue" (Kigongo, 2012) and warned "Ugandans who are choosing to promote illegality should not abuse the rights of the majority" (Namutebi, 2009). Moreover, the racial and sexual politics underpinning conservative attacks against gay and lesbian rights are clearly exemplified in Pastor Martin Ssempa's letter to Human Rights Watch (a U.S.-based organization):

I can certainly understand why organizations like yours [Human Rights Watch] want people to think that homosexuality is fixed, like race, and cannot be changed, because you know that would make people more sympathetic to your "sexual rights" agenda which conflicts with the strong family values of Uganda. (Ssempa, 2007)

Within these antigay right and nationalist discourses, homosexuality and race are constructed as distinct and mutually exclusive categories, albeit in ways that identify homosexuality with the West (and implicitly raced White) and Blackness with an earlier colonial era script of natural heterosexuality. For anti-immutability arguments to be effective, conservative forces position heterosexuality as outside power relations, which has been widely challenged by critical sexuality and gender studies that contest the homosexual/ heterosexual binary by revealing the multiple understandings of sexual practices and identities across time and space and highlighting the multiple and intersecting systems of power that both bring sexuality into being and attempt to regulate it according to narrow hetero-patriarchal norms (see Hoad, 2007). Moreover, conservative religious and political actors exert enormous efforts to construct Uganda as a God-fearing, family-oriented nation that is under moral attack by liberal, secular forces. While some of these forces are internal to Uganda, like the national media or the failure of parents to instill "good" values (see Sadgrove et al., 2012), transnational antigay activists are principally concerned with what they perceive as an encroaching "global gay agenda" that "wants to create a utopia with a new moral compass where there is absolutely no restriction on sexual practices" and replace the "marriagebased family with sexual anarchy" (Langa, 2009).

\section{The Global Gay Agenda and Seduction}

Within this discourse, children are frequently seen as particularly vulnerable to moral corruption and persuasion, and therefore require protection from 
sexual predators and homosexual seduction. The "homosexual as predator" theme is clearly visible in the vicious antigay campaign that was launched by a weekly tabloid, Rolling Stone, in October 2010. In addition to publishing the personal details of members of the LGBTI community, the tabloid went so far as to claim that the gay movement aims to "recruit 1,000,000 children by 2012 " and an inside headline read "Hang them; they are after our kids." A similar message was delivered by Stephen Langa at his antigay workshop: "what we're dealing with here is not a joke. And of course, their cause- they don't care about you. They want your children!" (Langa, 2009). The direct influence of CR literature on Uganda's antigay campaigns is clearly apparent in Langa's antigay seminar, where he described Richard Cohen as one of "the most authoritative writers who has written on the subject [of homosexuality]" (ibid). This is particularly alarming not only because Cohen was expelled in 2002 from the American Counseling Association for ethics violations, but also because his text, "Coming Out Straight" (2000), cites the widely discredited research of Dr. Paul Cameron (director of the Family Research Institute, Colorado Springs) that claims homosexuals are more likely to abuse children. ${ }^{8}$ Langa's performance also included a dramatic narration of a passage from Michael Swift's (1987) "Gay Revolutionary," which is somewhat of a staple in CR publications (Herman, 1997), including Lively's "Redeeming the Rainbow." Despite the text's explicit satirical nature, trans/ national antigay campaigns use it as "evidence" of an elaborate homosexual conspiracy to take over the world.

Sadgrove and others (2012) draw our attention to the profound anxieties in Uganda over the power of money to motivate immoral behavior, including homosexuality. For instance, numerous newspaper articles report on the widely held perception that homosexuality is on the rise in secondary schools, especially same-sex boarding schools (Ahimbisibwe, 2005; Businge, 2007; Buyera, 2009), with religious and political leaders warning young people against "receiving money from people who may want to lure them into homosexuality" (Mugabi, 2009). Understandings of money as having a corruptive influence on sexual morality implicate "sexual morality in a critique of the ways in which the capitalist order disrupts kinship solidarities" (Sadgrove et al., 2011, p. 117). These concerns also reveal the tensions that lie at the heart of postcolonial identity, which, as Hoad (2007) notes, involves defending the nation as an agent of modernity in terms of economic and cultural progress and as the custodian of tradition and morality. It is perhaps little surprise, given the continued imposition of neoliberal development policies on the global South by Northern actors, that international donors and organizations are singled out as the main threats to "African" tradition and the global financiers/promoters of homosexuality in the country. As Reverend Kasibante (2009) explains, "the threat must be built into a real threat. So it is said that there is a heavily funded campaign from USA and Europe to promote homosexuality in Uganda's institutions" (Anonymous, 2009a). In a statement issued to Parliament, James Nsaba Buturo warned that many schools had been infiltrated by international organizations (like 
Amnesty International, UNICEF, and Human Rights Watch) and that these organizations work discreetly and with local groups to spread homosexuality in the local population (in Olupot and Musoke, 2009). The understanding that the "West and their puppets are doing all they can to train little children to be gays so as to have a following" (Walakira, 2003) relies on a particular construction of the global gay movement as "a well-funded and organized homosexual machinery" (Langa in Vision Reporters, 2009) that threatens to morally corrupt and destroy "African" culture and tradition.

\section{Homosexuality as "un-African"}

In Uganda, as in other formerly colonized settings in Africa, denouncing homosexuality as "un-African" not only represents an explicit rejection of "new" universal sexual norms and continued neocolonial influences but it also seeks to construct a postcolonial national identity that is based on a fictive and essentialist understanding of "African" culture. President Museveni has articulated this position on numerous occasions in commending the Church for "resisting homosexuality, a decadent culture being passed on by the Western nations" (Eyalama, 2008; see also Kagolo, 2010; Olupot and Edyegu, 2008). Similar statements are echoed in national newspapers. For example, Archbishop Orombi has claimed, "in Uganda, homosexuality is against our culture" (Vision Reporters, 2010b), and James Buturo has identified homosexuality as "repulsive to our culture and traditions" (2005) and, on a different occasion, claimed "we shall not allow those people from the West to define our identity and destiny" (in Anonymous, 2009b). An editorial reminded readers that, "homosexuality never existed in Africa before the external cultures were introduced here ... Engaging in homosexuality is ... not part of our history or tradition" (Ankunda, 2006).

In their varied ways, statements declaring the "un-African-ness" of homosexuality rely on making claims to culture - imagined as a particular way of life that is historically fixed, authentic, belonging to a group of peoples, and fundamentally different from the "West." Within these narratives, sexuality represents a key marker of post-colonial identity and sovereignty and a site where ideological independence from Western influences is expressed. One of the most common ways conservative evangelicals express "African" resistance to homosexuality is through a retelling of the story of the Ugandan Martyrs; the execution of more than thirty Christian pages in 1886 by Kabaka Mwanga (the King of the Baganda monarchy) for resisting his homosexual advances. Each year, on June $3^{\text {rd }}$, the Martyrs are honoured for their courage in resisting sexual immorality in Mwanga's palace. The Martyrs have come to represent the quintessential Christian subject: "Their faith in Christ emboldened them to stand against homosexuality, resisting to the point of shedding blood" (Ssempa, 2009). Although there are a number of frameworks through which this event could be told (see Hoad, 2007)—such as the dangers of intolerant dictatorships, the Kabaka's resistance to colonial expansion and 
rule, or the colonial making of an (abject) homosexual subject — the dominant framework that conservative Christians use in their recounting emphasizes the irreconcilable tensions between (White) homosexuality and (heterosexual) "African" culture to make the point that Ugandan Christians will accept death before they accept homosexuality. Notwithstanding the explicit ironies that underpin this narrative, notably the colonial imposition of Christianity and "civilized" sexual norms themselves, the Martyrs have become an important transnational symbol of antigay sentiment and resistance. Moreover, the symbolic caricature of King Mwanga as a homo-despotic ruler who imposed an anti-Christian morality on "unwanting" subjects has a remarkable similarity to the representations conservative Christians invoke concerning the global "gay agenda" (see Ssempa, 2005; 2009).

The framing of homosexuality as "un-African" and a neocolonial imposition not only erases the colonial roots of Christianity, but also the sexual pluralism and diversity that comprise African cultures and traditions. In the words of the director of a Ugandan NGO, "You know the funny thing is monogamy is a Western import, more than homosexuality actually" (personal interview March 2011). The same sentiment is echoed in a newspaper article published in The Independent:

Those opposed to homosexuality argue that it is un-African. But they do not point to any specific tradition and cultural sanctions against gays in any particular pre-colonial African society. Instead, they point to Christianity - a religion that is not African and is indeed against many African traditions. (Mwenda, 2009)

A rich body of scholarship on African sexualities and identity politics poses a tremendous challenge to antigay claims made in the name of some "pure" and "timeless" "African culture." These studies show that African cultures are no more homogeneous in sexual practices than those found elsewhere in the world. Same-sex relationships have been documented among different peoples (e.g., in Uganda among the Banyoro, the Iteso, the Baganda) (Tamale, 2007) and social approval of same-sex intimacies has varied enormously across time and space. As Hoad (2007) argues, it is impossible to assign any single meaning to same-sex intimacies; they have assumed numerous social meanings in the African context ranging from sin to the most noble form of love, as well as a means to establish hierarchy or exercise political resistance through history. Moreover, in her public address at Makerere University, Sylvia Tamale provided numerous examples of sexual and familial diversity within African cultures (including marriages between blood-related kin and non-sexual female partnerships), arguing it is "next to impossible to mark a particular institution as the one and only 'traditional' African family" (2009). The antigay assertions that homosexuality offends "African" culture and tradition or that Ugandans must endlessly oppose homosexuality for the sake of the nation rely on an imagined and essentializing construction of culture that has never existed in reality. As Desiree Lewis eloquently remarks, "invocations of static culture are fictions. Even the most seemingly pristine and unchanged cultural practices are affected by history, globalization, and 
social struggles" (2011, p. 210). A director from a Ugandan NGO that supports transgender and intersex people also noted, "We are closing our eyes to the fact that our culture is changing, we're being affected by modernization, and we have to adapt, we just have to adapt" (personal interview March 2011). Anti-colonial rhetoric and claims to "African" culture can be read, on the one hand, as an attempt to "defend institutions of the nation and family that are increasingly hamstrung in the reproduction of social life under neoliberalism" (Hoad, 2007, p. 66), and as a potent tool for political and religious leaders to legitimate and maintain authoritarian and hetero-patriarchal forms of power, on the other.

For instance, critical commentaries have highlighted how the "resurrection of official gay-bashing" (Olopade, 2012) diverts from view the government's neglect of socio-economic issues and official abuses of authority (which, for the most part, have been met with silence by Northern donors and conservative Christians). The rise of public dissent and protest movements in the country (such as the recent Walk-to-Work campaign led by opposition leader Kizza Besigye) suggests that ordinary Ugandans are not just equally, but more concerned with the deepening inequalities accompanying global neoliberalism and the government's illiberal (and often militaristic) response to political dissent than with further criminalizing homosexuality. Critics have also charged the government with spending reckless amounts of money on fighter jets, Museveni's 2011 re-election campaign, and his swearing-inceremony, while the country faces soaring costs of living, an insufficient social infrastructure (like health), staggering unemployment rates (especially for youth) and, for those with employment, poor labour conditions and wages (Gatsiounis, 2011; Ssenkabirwa, 2012).

\section{Conclusion}

This paper has sought to provide a contexualized understanding of Uganda's Anti-Homosexuality Bill through an analysis of the transnational and local forms of knowledge and power struggles that shape conservative antigay activism in the country. As this paper demonstrates, much of the highly charged antigay rhetoric underpinning the campaigns of Uganda's evangelical leaders resonates with $\mathrm{CR}$ antigay discourses and, at times, is a direct reproduction of CR strategies and knowledge. However, I have also shown that conservative evangelicals in Uganda are not "passive" recipients of CR antigay discourses. Rather, their antigay positions are formulated with reference to culturally specific discourses and concerns over "African" culture and tradition, neocolonial influence and power, and struggles over national sovereignty and identity. Thus, it is more apt to see Ugandan antigay politics as taking on hybrid forms and articulations with transnational sources (like the U.S. Christian Right), rather than being determined by or produced in isolation from them. The legacies of colonialism and its "civilized" sexual norms, the flow of capital and the deepening inequalities accompanying 
neoliberal globalization, the transnational relationships that exist between the global North and South, and the global reach of the U.S. Christian Right's "pro-family" agenda complicate our understanding of the antigay politics in Uganda and the nationalist claims made in the name of some authentic and timeless "African" tradition and culture. While this paper has attempted to provide some insights into the various ways antigay claims intersect with global neoliberalism and the racial and sexual politics of colonial and U.S. Christian Right scripts of the "natural" family, further research is needed to investigate both the legacies and effects of how the historical interconnections between sexuality and racial otherness are manifested in both contemporary gay and antigay movements that transcend national borders, albeit in ways that are locally and culturally situated in post-colonial contexts.

\section{Acknowledgements}

The author gratefully acknowledges the many people in Uganda who contributed their time and insights to this research and the Uganda National Council for Science and Technology for granting her permission to conduct this research. She also acknowledges the financial support that was received by the CHSRF/CIHR Chair in Health Services at York University (Canada) and Wilfird Laurier University (from a grant partly funded by WLU Operating funds and partly by the SSHRC General Research Grant awarded to WLU). The author is grateful for the research assistance of Jesse Carlson and Kaitlyn Ammerman and the research support from PEALS at Newcastle University (UK) and the International Institute for the Sociology of Law (Spain). Finally, she thanks members of the Canadian Network for Critical Sociology, the SSJ Editors and the Reviewers for their helpful comments and suggestions on earlier versions of this article.

\section{Notes}

Wilfrid Laurier University, 73 George Street, Brantford, ON, N3T 2Y3, Canada

2 The Church of Uganda (Anglican) recommends amending existing legislation to address current loopholes associated with homosexuality, namely promotion, recruitment and dissemination of literature (Church of Uganda, 2009).

3 See the website for the Civil Society Coalition on Human Rights and Constitutional Law for video coverage of speeches made by Ugandan human rights activists: http://www. ugandans4rights.org/video_template.php.

4 It is important to note that sexual and gender norms have long been discussed and contested by Anglican bishops at the decennial Lambeth Conferences. In 1888, the Church condemned polygamy; one hundred years later (1988) Anglican bishops agreed to allow baptism to polygamous men and their families so long as they promised not to marry again (as long as the wives were alive) [Resolution 26, 1988]. An interesting question concerns how the CR reconciles its global "pro-family" agenda (which is defined in terms of heterosexual monogamy) with the existence of polygamy in many African countries. I am inclined to see the perceived threat that polygamy poses to White Christian sexual norms as minimized by polygamy's focus on male authority and the institution of hetero-patriarchal "marriage." 
5 For instance, President G.W. Bush reinstated the global gag rule, which prohibits family planning organizations from performing or providing information about abortions; his administration also institutionalized abstinence-only, pro-marriage and anti-prostitution directives into US foreign policy on HIV/AIDS and international trafficking.

6 In 2001, the Faith-Based and Community Initiatives Act was approved by Congress and a Faith-Based and Community Initiatives Office was established in the White House. This was followed by an Executive Order that led to the creation of similar offices in five governmental Departments, including the Agency for International Development (USAID). A 2004 ruling prohibited USAID from discriminating against organizations that combine development or humanitarian activities with religious activities, such as worship or religious instruction.

7 Close to $80 \%$ of Ugandans are Christians today, with roughly $40 \%$ of the population Protestant (Anglican, Orthodox, Pentecostal), 35\% Catholic and 10\% Muslim, and the remainder nonreligious or members of indigenous or minority religions like Hinduism. Because Buganda was so closely associated with colonial power and Anglican religion, its ties led to much resentment by other regions and peoples in Uganda, which may account for the slight majority held by Roman Catholicism in Uganda from the early $20^{\text {th }}$ century onward (Hassett 2007).

8 Paul Cameron's research is also cited in Scott Lively's text, "Redeeming the Rainbow" (2009a).

\section{References}

Ahimbisibwe, F. (2005, February 4). Students warned on homosexuality. New Vision. Retrieved from http://www.newvision.co.ug/PA/8/13/416267

Anderson, J. (2011). Conservative Christianity, the Global South and the battle over sexual orientation. Third World Quarterly, 32(9), 1589-1605.

Ankunda, P. (2006, September 25). Homosexuality is against nature and African culture. New Vision. Retrieved from http://www.newvision.co.ug/D/8/459/523164

Anonymous (2009a, May 25). Is the media promoting homosexuality? New Vision. Retrieved from http://www.newvision.co.ug/D/526/532/682489

Anonymous (2009b, November 30). Corridors of power. New Vision. Retrieved from http:// www.newvision.co.ug/D/8/459/702836

BBC News (2010, February 18). Uganda gay-porn stunt “twisted.” BBC News. Retrieved from http://news.bbc.co.uk/1/hi/world/africa/8522039.stm

Bill No. 18 (2009). The anti-homosexuality bill, Uganda. October.

Businge, C. (2007, September 27). Government drafts homosexuality bill. New Vision. Retrieved from http://www.newvision.co.ug/PA/8/12/589000

Buss, D. (2004). The Christian Right, globalization, and the "natural family." In M.A. Tétreault, \& R. Denemark (Eds.), Gods, guns \& globalization: Religious radicalism and international political economy (pp. 57-78). Boulder, CO: Lynne Rienner Publishers, Inc.

Buss, D. \& Herman, D. (2003). Globalizing family values: The Christian right in International Politics. Minneapolis/London: University of Minnesota Press.

Buturo, J. N. (2005, February 23). Why does New Vision promote homosexuals? New Vision. Retrieved from http://www.newvision.co.ug/D/8/459/419805

Buyera, B. (2009, September 30). MP blames boarding schools for homosexuality. New Vision. Retrieved from http://www.newvision.co.ug/PA/8/18/696270

Chamberlain, P. (2006). Undoing reproductive freedom: Christian Right NGOs target the United Nations. Retrieved from http://PublicEye.org

Church of Uganda (2009). Church of Uganda's position on the anti-homosexuality bill 2009. Kampala: Church of Uganda.

Civil Society Coalition (2009). Anti-homosexuality or anti-human rights bill? Kampala: Civil Society Coalition on Human Rights and Constitutional Law.

Cohen, R. (2000). Coming out straight: Understanding and healing homosexuality. Winchester, VA: Oakhill Press.

CNN (2001, September 14). Falwell apologizes to gays, feminists, lesbians. CNN U.S. Retrieved 
from http://articles.cnn.com/2001-09-14/us/Falwell.apology_1_thomas-road-baptist-churchjerry-falwell-feminists?_s=PM:US

Daly, L. (2001). A Church at Risk: The Episcopal "Renewal Movement." IDS Insights, 2(2), 1-12. Retrieved from http://www.idsonline.org/publications.html

DeParle, J. (1996, August 4). The Christian Right confesses sins of racism. New York Times. Retrieved from http://www.nytimes.com/1996/08/04/weekinreview/the-christian-rightconfesses-sins-of-racism.html?pagewanted $=$ all\&src $=$ pm

Eyalama, I. (2008, September 15). Ugandans should not embrace homosexuality. New Vision. Retrieved from http://www.newvision.co.ug/D/8/459/649714

Gatsiounis, I. (2011, April 23). Deadly crackdown on Uganda's walk-to-work protests. Time World. Retrieved from http://www.time.com/time/world/article/0,8599,2067136,00.html

Haritaworn, J. (2012). Women's rights, gay right and anti-Muslim racism in Europe: Introduction. European Journal of Women's Studies, 19(1), 73-78.

Hasselriis, K. (2010, March 15). Elderly bishop rocks Uganda's gay rights movement. Xtra! Canada's Gay \& Lesbian News. Retrieved from http://www.xtra.ca/public/National/Elderly bishop_rocks_Ugandas_gay_rights_movement-8359.aspx

Hassett, M. (2007). Anglican Communion in crisis: How Episcopal dissidents and their African allies are reshaping Anglicanism. Princeton: Princeton University Press.

Haynes, J. (2001). Transnational religious actors and international politics. Third World Quarterly, 22 (2): 143-158.

Hearn, J. (2002). The invisible NGO: US evangelical missions in Kenya. Journal of Religion in Africa, 32(1), 32-60.

Herman, D. (1997). The antigay agenda: Orthodox vision and the Christian Right. Chicago and London: The University of Chicago Press.

Hoad, N. (2007). African intimacies: Race, homosexuality and globalization. Minneapolis: University of Minnesota Press.

Hofer, K. (2003). The role of Evangelical NGOs in international eevelopment: A comparative case study of Kenya and Uganda. Africa Spectrum, 38(3), 375-398.

Huliaras, A. (2008). The evangelical roots of U.S. Africa policy. Survival, 50(6), 161-182.

Human Rights Watch (2009). Uganda: Anti-homosexuality bill threatens liberties and human rights defenders. New York: Human Rights Watch.

Human Rights Watch (2011). Uganda: Parliamentary committee backs anti-homosexuality bill. New York: Human Rights Watch.

Jackson, S. (2001). Why a materialist feminism is (still) possible - and necessary. Women's Studies International Forum, 24(3/4): 283-293.

Kagolo, F. (2010, June 3). Museveni warns on dangers of sodomy. New Vision. Retrieved from http://www.newvision.co.ug/D/8/12/721699?highlight\&q=homosexuality

Kalende, V. (2011, November 3). Cutting aid to repressive countries will not help fight for human rights. Daily Monitor. Retrieved from http://www.monitor.co.ug/OpEd/Commentary//689364/1266284/-/12pkj59z/-/index.html

Kaoma, K. 2009. Globalizing the culture wars: U.S. conservatives, African churches, and homophobia. Somerville, MA: Political Research Associates.

Kasibante, A. (2012). Revival and Pentecostalism in my life. In K. Ward \& E. Wild-Wood (Eds), The East African revival: History and legacies (pp. 61-68). Surrey: Ashgate Publishing Limited.

Kasibante, A. (2009, December 6). How homos got trapped in Africa's power politics. Daily Monitor. Retrieved from http://www.monitor.co.ug/OpEd/Commentary/-/689364/818892/-/ a19260z/-/index.html

Keck, M., \& Sikkink, K. (1998). Activists beyond borders: Advocacy networks in international politics. Ithaca, NY: Cornell University Press.

Kigongo, J. (2012, January 3). Gay activists lash out at Nsaba Buturo. Daily Monitor. Retrieved from http://www.monitor.co.ug/News/National/-/688334/1299482/-/bfh9c9z/-/index.html

Kwon, L. (2009, December 10). Uganda's antigay bill draws evangelical opposition. Christian Post. Retrieved from http://www.christianpost.com/news/uganda-s-antigay-bill-drawsevangelical-opposition-42225/

Langa, S. (2009, March 15). Follow up meeting on the homosexuals' agenda. Kampala. Retrieved from http://www.boxturtlebulletin.com/2009/03/28/10171

Lewis, D. (2011). Representing African sexualities. In S. Tamale (Ed.), African sexualities: A 
reader (pp. 119-216). Cape Town: Pambazuka Press.

Lewis, D. (2004). Introduction. In D. Lewis (Ed.), Christianity reborn: The global expansion of Evangelicalism in the twentieth century, pp. 1-8. Grand Rapids, MI: Wm. B. Eerdmans Publishing Co.

Lively, S. (2009a). Redeeming the rainbow: A Christian response to the gay agenda. Springfield, MA: Veritas Aeterna Press.

Lively, S. (2009b, March 5). Seminar on exposing the homosexuals' agenda. Kampala. Retrieved from http://wn.com/Scott_Lively

McWhorter, L. (2009). Racism and sexual oppression in Anglo-America: A genealogy. Bloomington and Indianapolis: Indiana University Press.

Mugabi, F. (2009, June 9). Bishop warns students against homosexuality. New Vision. Retrieved from http://www.newvision.co.ug/PA/8/12/589000

Muhanga, M. (2009, October 26). Neo-colonialism fuels hin Africa. New Vision. Retrieved from http://www.newvision.co.ug/D/8/459/699133

Muhofa, I. (2008, October 27). We must say no to homosexuality. New Vision. Retrieved from http://www.newvision.co.ug/PA/8/21/656631

Mwenda, A. (2009. December 15). Don't kill in God's name. The Independent. Retrieved from http://independent.co.ug/the-last-word/the-last-word/2269-dont-kill-in-gods-name

Namutebi, J. (2009, July 1). Uganda's anti-gay bill to be tabled soon. New Vision. Retrieved from http://www.newvision.co.ug/D/8/13/686525

Namutebi, J. (2008, September 14). Ssempa rewarded for antigay crusade. New Vision. Retrieved from http://www.newvision.co.ug/D/8/13/649677

Ni Chonghalle, C. (2012, February 8). Uganda antigay bill resurrected in parliament. The Guardian. Retrieved from http://www.guardian.co.uk/world/2012/feb/08/uganda-gay-deathsentence-bill

Olopade, D. (2012, February 22). Gay bashing, a government diversion. International Herald Tribune. Retrieved from http://latitude.blogs.nytimes.com/2012/02/22/gay-bashing-inuganda-is-a-diversion-from-government-malfeasance/

Olupot, M., \& Musoke, C. (2010, January 12). Museveni warns NRM on homo bill. New Vision. Retrieved from http://www.newvision.co.ug/D/8/12/706894

Olupot, M., \& Musoke, C. (2009, April 15). UNICEF, Amnesty promote homos. New Vision. Retrieved from http://www.newvision.co.ug/D/8/12/678189

Olupot, M., \& Edyegu, D. (2008, August 17). Museveni backs Church against gays. New Vision. Retrieved from http://www.newvision.co.ug/D/8/12/644954

Petchesky, R. (2000). Sexual rights: inventing a concept, mapping an international practice. In R. Parker, R. Barbosa, \& P. Aggleton (Eds.), Framing the sexual subject: The politics of gender, sexuality, and power, pp. 81-103. Berkeley, California: University of California Press.

Puar, J. (2007). Terrorist assemblages: Homonationalism in queer times. Durham, NC: Duke University Press.

Rolling Stone (2010, October 2). 100 pictures of Uganda's top homos leak (pp. 1). Rolling Stone.

Sadgrove, J., Vanderbeck, R., Andersson, J., Valentine, G., \& Ward, K. (2012). Morality plays and money matters: Towards a situated understanding of the politics of homosexuality in Uganda. Journal of Modern African Studies, 50(1), 103-129.

Seidman, S., Fischer, N., \& Meeks, C. (Eds.). (2006). Handbook of the new sexuality studies. New York, NY: Routledge.

Sharlet, J. (2008). The family: The secret fundamentalist at the heart of American power. New York, NY: Harper Collins.

Ssempa, M. (2005, June 2). When faith, state and state-inspired homosexuality clash. New Vision. Retrieved from http://www.newvision.co.ug/D/8/459/437768

Ssempa, M. (2007, September 4) Homosexuality is against our culture. New Vision. Retrieved from http://www.newvision.co.ug/D/8/459/584917

Ssempa, M. (2009) A letter to Rick Warren. Christianity Today. Retrieved from http://www. christianitytoday.com/ct/special/pdf/1217ssempaletter.pdf

Ssenkabirwa, Al-Mahdi (2012, April 7). Rising youth unemployment in Uganda, a ticking time bomb. Saturday Monitor. Retrieved from http://www.monitor.co.ug/ SpecialReports/-/688342/1381200/-/item/0/-/gawh35z/-/index.html

Stone, A., \& Ward, J. (2011). From "Black people are not a homosexual act" to "gay is the new black": mapping White uses of blackness in modern gay rights campaigns in the United 
States. Social Identities: Journal for the Study of Race, Nation and Culture, 17(5), 605-624.

Strand, C. (2011). Kill bill! Ugandan human rights organizations' attempts to influence the media's coverage of the anti-homosexual bill. Culture, Health \& Sexuality: An International Journal for Research, Intervention and Care, 13(8), 917-931.

Swift, M. (1987, February 15-21). Gay revolutionary. Gay Community News (reprinted from the Congressional Record). Retrieved from http://www.fordham.edu/halsall/pwh/swift1.asp

Tamale, S. (2011). Introduction. In S. (Ed.), African sexualities: A reader (pp. 1-7). Cape Town: Pambazuka Press.

Tamale, S. (2009). A human rights impact assessment of the anti-homosexuality bill. In The Civil Society Coalition on Human Rights and Constitutional Law (Ed.), Uganda's AntiHomosexuality Bill: The Great Divide (pp. 19-22). Kampala: The Civil Society Coalition on Human Rights and Constitutional Law.

Tamale, S. (2007). Out of the closet: Unveiling sexuality discourses in Uganda. In C. Cole, T. Manuh, \& S. Miescher (Eds.), Africa after gender? (pp. 17-29). Indiana: Indiana University Press.

The Washington Times (2005, June 7). African bishops reject aid. The Washington Times. Retrieved from http://www.washingtontimes.com/news/2005/jun/07/20050607-1154367061r/

Vision Reporters (2010a, October 23). Disturbing perception of salvation. New Vision. Retrieved from http://newvisionuganda.info/D/120/525/735913

Vision Reporters (2010b, August 25). African bishops maintain antigay stand. New Vision. Retrieved from http://www.newvision.co.ug/D/8/12/729779

Vision Reporters (2009, May 29). Is money fuelling the gay war? New Vision. Retrieved from http://www.newvision.co.ug/PA/9/621/682978

Walakira, G. (2003, February 10). Gay rights not a priority in Uganda. New Vision.

Ward, K. (2012). Introduction. In K. Ward \& E. Wild-Wood (Eds), The East African revival: History and legacies (pp. 3-10). Surrey: Ashgate Publishing Limited.

Wilcox, C. (1990). Blacks and the New Christian Right: Support for the moral majority and Pat Robertson among Washington, D.C. Blacks. Review of Religious Research, 32(1), 43-55. 